\title{
Dietary fat and asthma: is there a connection?
}

\author{
P.N. Black, S. Sharpe
}

\author{
Dietary fat and asthma: is there a connection? P.N. Black, S. Sharpe. (CERS Journals \\ Ltd 1997.
}

ABSTRACT: The last two decades have seen an increase in the prevalence of asthma, eczema, and allergic rhinitis in developed countries. This increase has been paralleled by a fall in the consumption of saturated fat and an increase in the amount of polyunsaturated fat in the diet. This is due to a reduction in the consumption of animal fat and an increase in the use of margarine and vegetable oils containing $\omega-6$ polyunsaturated fatty acids (PUFAs), such as linoleic acid. There is also evidence for a decrease in the consumption of oily fish which contain $\omega-3$ PUFAs, such as eicosapentaenoic acid.

In a number of countries, there are social class and regional differences in the prevalence of allergic disease, which are associated with differences in the consumption of PUFAs. Linoleic acid is a precursor of arachidonic acid, which can be converted to prostaglandin $\mathrm{E}_{2}\left(\mathrm{PGE}_{2}\right)$, whereas eicosapentaenoic acid inhibits the formation of $\mathrm{PGE}_{2}$. $\mathrm{PGE}_{2}$ acts on T-lymphocytes to reduce the formation of interferon- $\gamma(\mathrm{IFN}-\gamma)$ without affecting the formation of interleukin-4 (IL-4). This may lead to the development of allergic sensitization, since IL-4 promotes the synthesis of immunoglobulin $\mathrm{E}$ (IgE), whereas IFN- $\gamma$ has the opposite effect.

Changes in the diet may explain the increase in the prevalence of asthma, eczema and allergic rhinitis. The effects of diet may be mediated through an increase in the synthesis of prostaglandin $E_{2}$ which in turn can promote the formation of immunoglobulin $\mathbf{E}$.

Eur Respir J., 1997; 10: 6-12.
Dept of Medicine, University of Auckland, Auckland, New Zealand.

Correspondence: P.N. Black

Dept of Medicine

University of Auckland

Auckland Hospital

Private Bag 92024

Auckland

New Zealand

Keywords: Asthma

eczema

eicosapentaenoic acid

interferon- $\gamma$

linoleic acid

prostaglandin $\mathrm{E}_{2}$

Received: June 101996

Accepted after revision October 281996

\section{Changes in the prevalence of asthma}

Studies from the United Kingdom [1-5], Australia [6, 7], New Zealand [8, 9], Sweden [10], Finland [11], the United States [12] and Canada [13] of the same populations, years to decades apart, have provided good evidence of an increase in the prevalence of asthma in children and young adults over the last two decades. Where these studies have looked at changes in the prevalence of eczema and allergic rhinitis, they have found that these conditions have also increased. It appears that an increase in atopy, rather than just asthma, is occurring in developed countries.

\section{Why has the prevalence of asthma changed?}

A number of environmental factors, including air pollution, cigarette smoking, allergen exposure and diet, have been proposed as explanations for the changes in the prevalence of asthma. In a recent article, SEATON et al. [14] considered and rejected a number of these explanations. Air pollution has lessened in the UK since the 1950s with a fall in smoke and sulphur dioxide [14], and there is no clear evidence for a rise in ozone levels in the UK in the last two decades. Recent studies from Germany are of interest because they show that the prevalence of hayfever and asthma is lower in the more heavily polluted former German Democratic Republic (East Germany) [15]. Exposure to cigarette smoke in utero and in childhood increases the prevalence of allergic sensitization and respiratory disease [16], but there has been a steady fall over the last three decades in the proportion of the population who smoke, including women of childbearing age $[17,18]$. The evidence that exposure to house dust mite and other allergens has increased is disputed [7, 19]. Attention has focused on the role of the house dust mite in the pathogenesis of asthma, but there are communities, such as Los Alamos, where the prevalence of childhood asthma is comparable to other communities in the USA despite very low levels of house dust mite [20].

SEATon et al. [14] argue that the fall in the consumption of fresh fruit and vegetables in the UK between 1961 and 1985 may account for the increase in asthma. The idea that antioxidant vitamins, such as vitamin $\mathrm{C}$ and $\beta$-carotene, could have a protective effect in asthma is plausible and the main source of these vitamins is fruit and vegetables. There are, however, problems with this hypothesis. In 1965, a cohort from the National Child Development Study in the UK was followed up at 7 yrs of age. The lowest rates of asthma were reported in Scotland and the North of England [21], but in the National Food Survey conducted in 1969 [22] these were also the two regions with the lowest consumption of green vegetables and fresh fruit. Another study from the 
UK showed that the intake of vitamin $\mathrm{C}$ is lower in manual workers [23], whereas the prevalence of asthma is either unrelated to social class [24], or increases with higher social class [25].

In the rest of this article, we review the evidence for the hypothesis that an increase in the intake of $\omega-6$ fatty acids, such as linoleic acid, and a decrease in the intake of $\omega$-3 fatty acids, such as eicosapentaenoic acid, may have to led to an increase in allergic sensitization, which in turn may account for the increase in the prevalence of asthma. Chang et al. [26] and Hodge et al. [27] have previously suggested that changes in dietary fat may explain the increase in asthma but they did not relate this to changes in allergic sensitization.

\section{Changes in the consumption of linoleic acid}

In developed countries, there has been a fall in the consumption of saturated fat and an increase in the consumption of polyunsaturated fat, particularly linoleic acid, over the last few decades. It is thought that these changes have contributed to the fall in coronary heart disease mortality. In the USA between 1935 and 1939, linoleic acid accounted for only $9 \%$ of fatty acids in the food supply [28]. By 1984, this had risen to $15 \%$. These changes are in large part due to a decrease in the use of butter and lard and an increase in the use of margarine and vegetable oils. Figure 1 shows changes in adipose tissue linoleate in the USA, UK and Australia.

The argument for a connection between polyunsaturated fat and asthma would be more compelling if the increase in the consumption of linoleic acid antedated the rise in the prevalence of asthma. In the USA, the amount of linoleic acid (grams per capita per day) in the diet has increased over the last eight decades, with the change being most marked since the early 1960s [28]. YUNINGER et al. [12] found a steady increase in the incidence of asthma in children since 1964. This is what one would anticipate if the increase in the consumption of linoleic acid was contributing to the rise in the prevalence of asthma. In contrast, the increase in the consumption of linoleic acid in the UK occurred in the

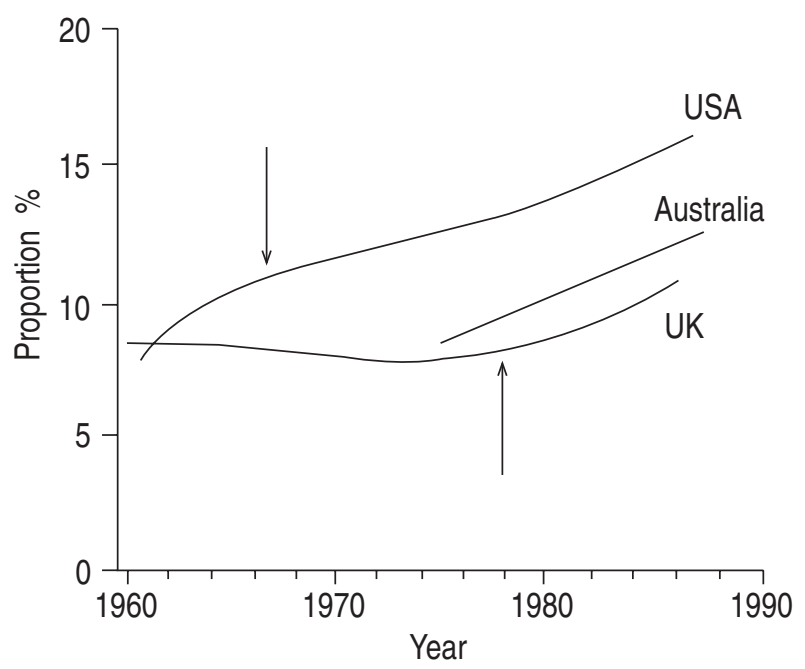

Fig. 1. - Proportion of linoleate in adipose tissue by country, 1960-1990. Arrows indicate year of down turn in coronary heart disease (CHD) death rate. (Reproduced from RoBERTs [29]). 1970s [29]. It is not entirely clear when the prevalence of childhood asthma began to rise in the UK but it may well have been in the early 1980s. In a review, ANDERSON [30] found little evidence for an increase in the prevalence of asthma in studies conducted prior to 1980 . In contrast, BURR et al. [1] found an increase in the prevalence of asthma in children in Wales between 1973 and 1988, while BURNEY et al. [3] found an increase in children in England between 1973 and 1986. If we accept that the prevalence of childhood asthma in the UK did increase in the early 1980s, it is consistent with the rise in the consumption of linoleic acid preceding the increase in the prevalence of asthma by several years.

\section{Changes in the consumption of oily fish}

The suggestion that oily fish may protect against the development of asthma stems from the observation that asthma is uncommon amongst the Eskimos, who have a high intake of fish oil [31]. Schwartz and Weiss [32] analysed data from the Second National Health and Nutrition Survey in the USA, and found that dietary fish intake was protective against wheezing but, in a stepwise logistic regression, were unable to show that this was independent of other nutrients. Recently, HoDGE et al. [33] reported a study of 584 children in Sydney, Australia. If the children included oily fish, such as salmon, tuna and sardines, in their diet the odds ratio for having current asthma was reduced to 0.26 (95\% confidence interval (95\% CI) 0.09-0.72). The diets of the children with current asthma did not differ from the normal children in any other regard and a protective effect was not seen with other types of fish.

Less information is available on trends in the consumption of oily fish than for changes in consumption of margarine and vegetable oils. In 1985, in the USA, the consumption of fish had increased compared with 1935-1939, but the levels of eicosapentaenoic acid in the diet were lower because of a marked decline of some oily fish in the diet [34]. Hodge et al. [33] speculated that the eicosapentaenoic acid, present in oily fish, may account for the protective effect which they observed. Some commentators [35] have argued that the observations by HoDGE et al. [33] are inconsistent with studies which failed to show improvement in asthmatics treated with fish oil [36-38]. If, however, fish oil exerts its beneficial effect by reducing the risk of allergic sensitization rather than having a direct effect on asthma this conflict no longer exists.

\section{Regional differences in asthma}

Regional differences in the intake of polyunsaturated fat have been reported in a number of countries, and this provides the opportunity to compare the prevalence of asthma in these regions with the differences in diet. Studies which have looked at the prevalence of asthma and allergic rhinitis in Germany following reunification demonstrate a lower incidence of atopic disease in the former East Germany. KRAMER et al. [39] studied more than 4,000 preschool children in several towns in Germany, and found lower prevalences of doctor-diagnosed 
asthma and rhinitis in children from the former East Germany. Von Mutius and co-workers [40, 41] compared 9 year old children in Leipzig in East Germany $(n=1,051)$ and Munich in West Germany $(n=5,030)$. The lifetime prevalence of asthma diagnosed by a doctor was $7.3 \%$ in Leipzig and $9.3 \%$ in Munich. A positive cold air challenge (defined as a 9\% fall in forced expiratory volume in one second (FEV1)) occurred in $6.4 \%$ of the children in Leipzig and $7.7 \%$ in Munich. The most striking difference was seen with the diagnosis of hayfever, which was $2.4 \%$ in Leipzig compared with $8.6 \%$ in Munich. Another study compared 7,200 subjects, aged 20-44 yrs, in Erfurt (East Germany) and Hamburg (West Germany) [42], and found higher prevalences of asthma and allergic rhinitis in Hamburg. These findings suggest that the differences between East and West Germany may be due to differences in allergic sensitization. This is supported by another study comparing 901 pupils from Leuna (East Germany) and Duisberg (West Germany) [43], which showed the prevalence of specific immunoglobulin (IgE) antibodies to house dust mite and cat was more than fivefold and threefold higher, respectively, in Duisberg.

There are fewer direct comparisons of food intakes in East and West Germany. Prior to unification, however, similar methodology was used to compare food intakes in Erfurt (East Germany) and Augsburg (West Germany) as part of the Monitoring of Trends and Determinants in Cardiovascular Disease (MONICA) project [44]. The survey involved middle-aged men keeping 3 day records of their food intake. The most striking difference was the higher intake of saturated fat in Erfurt, where the median daily intake of butter was $27 \mathrm{~g}$ higher than Augsburg. In contrast, margarine was consumed less frequently in Erfurt, with only $35 \%$ of men using it compared with $67 \%$ of men in Augsburg. At this time, margarine was less readily available and not as palatable in East Germany [44]. Increased consumption of margarine leads to a higher intake of linoleic acid, and we suspect that the higher incidence of asthma and other allergic diseases in West Germany at the time of reunification could be related to a higher intake of linoleic acid.

Finland has a low ratio of polyunsaturated fat to saturated fat in the diet (P:S ratio) and a high prevalence of ischaemic heart disease. The P:S ratio is lowest, and the prevalence of ischaemic heart disease is highest, in the east of the country. There are also regional differences in the prevalence of childhood asthma in Finland. In 1980, a cross-sectional study of risk factors for coronary heart disease was conducted in 3,596 Finnish children, aged 3-18 yrs, both in urban and rural areas in the south, the north and the east [45]. As part of the study, a questionnaire was sent to parents asking about chronic illnesses, including bronchial asthma, allergic rhinitis and atopic eczema [46]. The prevalence of asthma and allergic diseases was lowest in Eastern Finland (table 1). In Southern Finland, the prevalences of asthma and rhinitis (per 1,000 children) were 21 and 80, respectively, compared with values of 6 and 50, respectively, in Eastern Finland. In this study, the fatty acid composition of serum cholesterol esters was also measured in 1,348 children [47]. The levels of $\omega-6$ fatty acids, i.e. linoleic acid and arachidonic acid, in the cholesterol esters were significantly lower in children from
Table 1. - Prevalence (patients per 1,000 children) of bronchial asthma, allergic rhinitis and dermatitis, in 1980 in three areas of Finland

\begin{tabular}{lccc}
\hline & \multicolumn{3}{c}{ Patients per 1,000 children } \\
& $\begin{array}{c}\text { Northern } \\
\text { Finland }\end{array}$ & $\begin{array}{c}\text { Southern } \\
\text { Finland }\end{array}$ & $\begin{array}{c}\text { Eastern } \\
\text { Finland }\end{array}$ \\
\hline Asthma & $33^{*}$ & $21^{*}$ & 6 \\
Rhinitis & 59 & $80^{\ddagger}$ & 50 \\
Eczema & $54^{\#}$ & 49 & 31 \\
\hline
\end{tabular}

$*: \mathrm{p}=0.003 ;: \mathrm{p}=0.03$; $: \mathrm{p}=0.04$, significance of difference compared to Eastern Finland. (Adapted from Poysa et al. [46]).

Table 2. - Percentage composition of serum cholesteryl esters fatty acids in rural children from three areas in Finland

\begin{tabular}{lccc}
\hline & $\begin{array}{c}\text { Northern } \\
\text { Finland } \\
(\mathrm{n}=46)\end{array}$ & $\begin{array}{c}\text { Southern } \\
\text { Finland } \\
(\mathrm{n}=369)\end{array}$ & $\begin{array}{c}\text { Eastern } \\
\text { Finland } \\
(\mathrm{n}=275)\end{array}$ \\
\hline Linoleic acid & 50.21 & 51.26 & 47.90 \\
Arachidonic acid & 5.60 & 5.82 & 5.48 \\
EPA & 1.30 & 1.12 & 1.39 \\
\hline
\end{tabular}

EPA: Eicosapentaenoic acid. (Adapted from Molllanen et al. [47]).

Eastern Finland compared with those in the South or North. These differences are seen most clearly in the rural children (table 2). Furthermore, the levels of eicosapentaenoic acid, an $\omega-3$ fatty acid, were significantly higher in the cholesterol esters from the children in the east of the country. These findings are consistent with the observation that the consumption of fish, which contains eicosapentaenoic acid, is higher in the East. We believe that the lower levels of $\omega-6$ polyunsaturated fatty acid (PUFA) and higher levels of $\omega-3$ PUFA in the cholesterol esters of children in the east of Finland explains why allergic diseases occur less frequently in this part of the country.

There is evidence that the prevalence of atopy is increasing in Japan. NAKAGOMI et al. [48] reported that the prevalence of one or more positive skin tests for common allergens in 13-14 year old girls increased from $21.4 \%$ in 1978 to $39.4 \%$ in 1991 . In another study, middle-aged women eating a more traditional diet had a higher $\omega-3 / \omega-6$ ratio in their serum phospholipids than urban women of the same age [49]. The increase in atopy in Japan could be due to a decrease in the $\omega-3 / \omega-6$ ratio as more individuals eat a less traditional diet.

\section{Socioeconomic status, dietary fat and asthma}

Studies of the prevalence of coronary heart disease have shown that, in developed countries, coronary heart disease is commoner in individuals of lower socioeconomic status and those with less education [50]. These observations have been explained by differences in risk factors for coronary heart disease, such as smoking, and the intake of polyunsaturated as opposed to unsaturated fat. If the intake of dietary fat influences the prevalence of asthma one might also expect there to be socioeconomic differences in the prevalence of asthma and other 
allergic diseases. Indeed, this appears to be the case, with an increased frequency of allergic diseases in higher socioeconomic groups.

A number of studies over the last few decades have reported a greater prevalence of asthma in higher socioeconomic groups $[25,51,52]$. Some of these studies have been criticised because children with asthma may have been misclassified as wheezy bronchitis. One study which avoids this problem is a recent report by LEwIS et al. [25]. They used information from the 1970 British Cohort Study, which included all children born in Britain during the period 5-11 April 1970. These authors included all children where there was a positive response at the age of $5 \mathrm{yrs}$ to the question "Has the child ever wheezed". No distinction was made between asthma and wheezy bronchitis. Socioeconomic status was expressed as a social index, which combined information on parental occupation, education, income and housing conditions. Wheeze up to 5 yrs was greatest in the most disadvantaged group but there was no longer any independent effect of social index once other factors, such as birth weight and maternal smoking, were taken into account. In contrast, at 16 yrs, $18.3 \%$ of children in the most socially advantaged group were still wheezing compared with only $10.5 \%$ in the most disadvantaged group, and this was statistically significant.

These authors suggested that two distinct processes are involved. The associations between maternal smoking, low birth weight and wheezing in preschool children may be due to viral illnesses precipitating wheezing in children with small airways. On the other hand, wheeze persisting into adolescence occurs more frequently in higher socioeconomic groups and is more likely to represent allergic asthma. This interpretation is consistent with a study from Tucson in Arizona [53], where children who had wheezing before the age of $3 \mathrm{yrs}$, but in whom wheezing was no longer present at $6 \mathrm{yrs}$, had a reduction in tests of airway function but did not have elevated levels of IgE. In contrast, those who were still wheezing at $6 \mathrm{yrs}$ had elevated levels of $\mathrm{IgE}$, i.e. it is wheezing in later childhood that is most clearly associated with allergic sensitization.

The Nottingham group have gone on to demonstrate that there is a greater degree of allergic sensitization in those of higher socioeconomic status [54]. Skin sensitivity to five common aeroallergens was higher in social class I $(33 \%)$ than in social class V (28\%). Similar findings have been reported from the US with the second National Health and Nutrition Examination Survey (NHANES II) [55]. Rates of skin test reactivity to eight common allergens increased both with higher socioeconomic status and higher levels of education. Twenty five percent of white subjects with 13 or more years of education had one or more positive skin tests. In contrast, only $12.2 \%$ with 8 yrs of education or less were skin test positive. The prevalence of eczema and allergic rhinitis in children has also been reported to increase with higher socioeconomic status. Williams et al. [56] used information from the 1970 British National Cohort Study, and found that the point prevalences of eczema based on a physical examination at 7 yrs of age showed a similar socioeconomic gradient.

If there are socioeconomic differences in the prevalence of allergic diseases, what is the evidence for differences in the intake of dietary fat? In the Coronary Artery Risk Development in Young Adults (CARDIA) study, dietary assessments were performed in 1985-1986 on 5,111 individuals in the US aged 18-30 yrs. High school graduates (i.e. 12 or more years of education) had a higher P:S ratio than those with less education [57]. Two studies from Scotland have also looked at social class differences in the intake of polyunsaturated and saturated fat. Fulton et al. [58] studied 129 males (44-54 yrs of age) who kept detailed dietary records. In this study, nonmanual workers consumed significantly more linoleic acid than manual workers. In a larger study, BolTON-SMith et al. [59] administered a food frequency questionnaire to over 10,000 Scottish males and females aged 40-59 yrs, and found that the P:S ratio was lower in nonmanual workers, both for females (nonmanual 0.31 , manual $0.28 ; \mathrm{p}<0.001$ ) and for males (nonmanual 0.32 , manual $0.31 ; \mathrm{p}=0.025$ ). These findings are consistent with our hypothesis that an increase in the intake of polyunsaturated fat may contribute to the higher rates of allergic disease observed in higher socioeconomic groups. The differences in the P:S ratios between groups in these studies are relatively small, however, and other factors may also contribute to the differences observed between socioeconomic groups in the prevalence of atopic disease.

\section{Prospective studies of diet and respiratory disease}

There is a need for a prospective study of a cohort of children who have a dietary assessment and who are then followed to determine whether they develop positive skin tests and/or asthma. Studies in adults have examined the relationship between diet and respiratory disease, but none of them has addressed the issue of whether a diet high in polyunsaturated fat prediposes to allergic sensitization. In Zutphen in the Netherlands, 793 middle-aged males were followed from 1960-1985 [60]. The intake of linoleic acid was positively associated with the risk of developing chronic nonspecific lung disease but $74 \%$ were smokers, so it is likely that most had chronic obstructive pulmonary disease (COPD) rather than asthma. The relationship between diet and the onset of adult asthma was examined in 77,866 females in the Nurse's Health Study [61]. No significant association was found between the intake of polyunsaturated fat and the risk of adult onset asthma. However, in adult onset asthma many, if not most, individuals are not atopic, so these findings are probably of limited relevance to the prevalence of atopic disease in childhood.

\section{Cytokines and $\mathrm{PGE}_{2}$}

The formation of IgE by B-lymphocytes is influenced by cytokines produced by T-helper (CD4+) lymphocytes. These CD4+ cells can be characterized by the profile of cytokines which they produce. Type 1 T-helper (Th1) cells produce interleukin-2 (IL-2) and interferon$\gamma($ IFN- $\gamma$ ) while type 2 T-helper (Th2) cells produce the cytokines, interleukin-4 (IL-4) and interleukin-5 (IL-5) $[62,63]$. However, the majority of CD4+ uncommited cells are T-helper (Th0) cells and produce a mixed 
cytokine profile. IL-4 acts to commit B-cells to the synthesis of IgE [64], whereas IFN- $\gamma$ inhibits the formation of $\operatorname{IgE}[65]$.

There is evidence that prostaglandin $\left(\mathrm{PGE}_{2}\right)$ can modulate the formation of cytokines by T-lymphocytes. Low concentrations of $\mathrm{PGE}_{2}\left(10^{9}-10^{8} \mathrm{M}\right)$ inhibit the formation of IL-2 and IFN- $\gamma$ by peripheral blood lymphocytes, whilst having no effect on the production of IL-4 and IL-5 $[66,67]$. The ability of $\mathrm{PGE}_{2}$ to inhibit the production of IFN- $\gamma$, but not IL-4, was not limited to clones of Th1 and Th2 cells but was also seen with Th0 cells. By inhibiting the formation of IFN- $\gamma$ but not IL$4, \mathrm{PGE}_{2}$ will increase the formation of IgE. There is also evidence that $\mathrm{PGE}_{2}$ can act directly on B-cells to stimulate the formation of IgE. ROPER and co-workers $[68,69]$ have reported that $\mathrm{PGE}_{2}$ promotes the action of IL-4 to increase the number of B-lymphocytes producing $\operatorname{IgE}$. If $\mathrm{PGE}_{2}$ increases the formation of $\operatorname{IgE}$ we believe that dietary factors which promote the formation of $\mathrm{PGE}_{2}$ could lead to the development of atopic disease in susceptible individuals.

Prostaglandins such as $\mathrm{PGE}_{2}$, are formed by the action of cyclo-oxygenase on arachidonic acid. Arachidonic acid, in turn, is formed from linoleic acid. As a result, an increase in linoleic acid in the diet will promote the formation of prostaglandins [70]. Dietary $\omega-3$ fatty acids have the opposite effect. The $\omega-3$ fatty acids can act in two ways to modulate the formation of $\mathrm{PGE}_{2}$ from arachidonic acid [70]. There is competitive inhibition between linoleic acid, and $\omega-3$ fatty acids, such as linolenic acid. Increasing dietary $\omega-3$ fatty acids results in a reduction in arachidonic acid by inhibiting its synthesis from linoleic acid. Omega-3 fatty acids also act to inhibit the action of cyclo-oxygenase. Of the $\omega-3$ fatty acids, eicosapentaenoic acid and docosahexaenoic acid (which are found in oily fish) are the most effective at inhibiting cyclo-oxygenase.

These effects have been demonstrated in vivo. KNAPP and FitzGerald [71] compared the effects of a 1 month supplementation with fish oil (containing eicosapentaenoic acid) and safflower oil (containing linoleic acid). The safflower oil diet led to a significant increase in the urinary excretion of a prostaglandin E metabolite, whereas there was a trend for a reduction in the excretion of the PGE metabolite with fish oil. However, pharmacological doses of linoleic acid were administered in this study. BlAIR et al. [72] addressed this issue by studying the effect of supplementation with lower doses of $\omega-6$ PUFA, and still demonstrated an increase in the excretion of urinary $\mathrm{PGE}_{2}$. A diet high in linoleic acid also reduced excretion of the metabolites of thromboxane- $\mathrm{A}_{2}$, although the relevance of this to asthma or other allergic diseases is not clear.

\section{Summary}

We hypothesize that dietary polyunsaturated fatty acid influences the development of allergic sensitization by increasing the formation of prostaglandin $E_{2}$; which, in turn, promotes $\mathrm{Th} 2$ responses and stimulates the formation of immunoglobulin E. An increase in the amount of linoleic acid in the diet will increase the formation of prostaglandin $\mathrm{E}_{2}$, while an increase in eicosapentaenoic acid has the opposite effect. This provides an explanation for how the changes in diet that have occurred in the last few decades may have led to the striking increases in allergic disease. It is important to recognize that the changes in lifestyle that have occurred in the developed world have not been limited to changes in the consumption of dietary fat and other factors may also be involved in the increase in the prevalence of asthma and other allergic diseases.

Acknowledgements: The authors would like to thank W. Lubbe, E. Mitchell and B. Salmon for their helpful comments and suggestions.

\section{References}

1. Burr ML, Butland BK, King S, Vaughan-Williams E. Changes in asthma prevalence: two surveys 15 years apart. Arch Dis Child 1989; 64: 1452-1456.

2. Fleming DM, Crombie DL. Prevalence of asthma and hayfever in England and Wales. Br Med J 1987; 294: 279-283.

3. Burney PGJ, Chinn S, Rona RJ. Has the prevalence of asthma increased in children? Evidence from the national study of health and growth 1973-1986. BMJ 1990; 300: 1306-1310.

4. Anderson HR, Butland BK, Strachan DP. Trends in prevalence and severity of childhood asthma. BMJ 1994; 308: 1600-1604.

5. Omran M, Russell G. Continuing increase in respiratory symptoms and atopy in Aberdeen schoolchildren. BMJ 1996; 312: 34.

6. Robertson CF, Heycock E, Bishop J, Nolan T, Olinsky A, Phelan PD. Prevalence of asthma in Melbourne schoolchildren: changes over 26 years. BMJ 1991; 302 : 1116-1118.

7. Peat JK, van den Berg RH, Green WF, Mellis CM, Leeder SR, Woolcock AJ. Changing prevalence of asthma in Australian children. BMJ 1994; 308: 15911596.

8. Mitchell EA. Increasing prevalence of asthma in children. NZ Med J 1983; 96: 463-464.

9. Shaw RA, Crane J, O'Donnell TV, Porteous LE, Coleman ED. Increasing asthma prevalence in a rural New Zealand adolescent population: 1975-1989. Arch Dis Child 1990; 65: 1319-1323.

10. Aberg N. Asthma and allergic rhinitis in Swedish conscripts. Clin Exp Allergy 1989; 19: 59-63.

11. Haahtela T, Lindholm H, Bjorksten F, Koskenvuo K, Laitenin LA. Prevalence of asthma in Finnish young men. BMJ 1990; 301: 266-268.

12. Yuninger JW, Reed CE, O'Connell EJ, Melton LJ III, O'Fallon WM, Silverstein MD. A community-based study of the epidemiology of asthma. Am Rev Respir Dis 1992; 146: 888-894.

13. Manfreda J, Becker AB, Wang PZ, Roos LL, Anthonisen NR. Trends in physician-diagnosed asthma prevalence in Manitoba between 1980 and 1990. Chest 1993; 103: 151-157.

14. Seaton A, Godden DJ, Brown K. Increase in asthma: a more toxic enviroment or a more susceptible population? Thorax 1994; 49: 171-174.

15. Magnussen H, Jorres R, Nowak D. Effect of air pollution on the prevalence of asthma and allergy: lessons from the German reunification. Thorax 1993; 48: 879-881. 
16. Martinez FD, Cline M, Burrows B. Increased incidence of asthma in children of smoking mothers. Pediatrics 1992; 89: 21-26.

17. MacFarlane JE, Jamrozik K. Tobacco in Western Australia: patterns of smoking among adults from 1974 to 1991. Aust J Public Health 1993; 17: 350-358.

18. From the CDC. Cigarette smoking among women of reproductive age: United States, 1987-1992. JAMA 1994; 272: 1649-1650.

19. Sporik R, Holgate ST, Platts-Mills TAE, Cogswell JJ. Exposure to house-dust mite allergen (Der $p$ I) and the development of asthma in childhood. $N$ Engl $J$ Med 1990; 323: 502-507.

20. Platts-Mills TA, Sporik R, Ingram JM, Honsinger R. Dog and cat allergens among school children in Los Alamos, New Mexico, USA: altitude 7,200 feet. Int Arch Allergy Immunol 1995; 107: 301-303.

21. Kaplan BA, Mascie-Taylor CGN. Biosocial factors in the epidemiology of childhood asthma in a British national sample. J Epidemiol Commun Health 1985; 39: 152-156.

22. Caygill CPJ, Hill MJ. Dietary patterns within the United Kingdom. In: Hill MJ, Giacosa A, Caygill CPJ, eds. Epidemiology of Diet and Cancer. E. Horwood, New York, 1994; pp. 201-212.

23. Braddon FEM, Wadsworth MEJ, Davies JMC, Cripps HA. Social and regional differences in food and alcohol consumption and their measurement in a national birth cohort. J Epidemiol Commun Health 1988; 42: 341-349.

24. Anderson HR, Bland JM, Patel S, Peckham C. The natural history of asthma in childhood. J Epidemiol Commun Health 1986; 40: 121-129.

25. Lewis S, Richards D, Bynner J, Butler N, Britton J. Prospective study of risk factors for early and persistent wheezing in childhood. Eur Respir J 1995; 8: 349-356.

26. Chang CC, Phinney SD, Halpern GM, Gershwin ME Asthma mortality: another opinion - is it a matter of life... and bread? J Asthma 1993; 30: 93-103.

27. Hodge L, Peat JK, Salome C. Increase consumption of polyunsaturated oils may be a cause of increased prevalence of childhood asthma. Aust NZ Med J 1994; 24: 727.

28. Raper NR, Marston RM. Levels and sources of fat in the US food supply. In: Ip C, ed. Dietary Fat and Cancer. Alan R. Liss, New York, 1986; pp. 127-152.

29. Roberts DCK. Dietary factors in the fall in coronary heart disease mortality. Prostaglandin Leukot Essential Fatty Acids 1991; 44: 97-101.

30. Anderson HR. Is the prevalence of asthma changing? Arch Dis Child 1989; 64: 172-175.

31. Horrobin DF. Low prevalence of coronary heart disease (CHD), psoriasis, asthma and rheumatoid arthritis in Eskimos. Are they caused by high dietary intake of eicosapentaenoic acid (EPA), genetic variation of essential fatty acid (EFA) metabolism or a combination of both? Med Hypotheses 1987; 22: 421-428.

32. Schwartz J, Weiss ST. Dietary factors and their relation to respiratory symptoms: the Second National Health and Nutrition Survey. Am J Epidemiol 1990; 132: 67-76.

33. Hodge L, Salome CM, Peat JK, Haby MM, Xuan W, Woolcock AJ. Consumption of oily fish and childhood asthma risk. Med J Aust 1996; 164: 137-140.

34. Raper NR, Cronin FJ, Exler J. Omega-3 fatty acid content of the US food supply. J Am Coll Nutr 1992; 11: 304-308.

35. Thien FCK, Woods RK, Walters EH. Oily fish and asthma: a fishy story? Med J Aust 1996; 164: 135-136.
36. Kirsch CM, Payan DG, Wong MYS, et al. Effect of eicosapentaenoic acid in asthma. Clin Allergy 1988; 18 : 177-187.

37. Arm JP, Horton CE, Mencia-Huerta J-M, et al. Effect of dietary supplementation with fish oil lipids on mild asthma. Thorax 1988; 43: 84-92.

38. Thien FCK, Mercia-Huerta J-M, Lee TH. Dietary fish oil effects on seasonal hayfever and asthma in pollen sensitive subjects. Am Rev Respir Dis 1993; 147: $1138-1143$.

39. Kramer U, Altus $\mathrm{C}$, Behrendt $\mathrm{H}$, et al. Epidemiologische Untersuchungen zur Auswirkung der Lufterverschmutzung auf die Gesundheit von Shulanfängern. Forum Städte Hygiene 1992; 43: 82-87.

40. Von Mutius E, Fritzsch C, Weiland SK, Roll G, Magnussen $\mathrm{H}$. Prevalence of asthma and allergic disorders among children in united Germany: a descriptive comparison. BMJ 1992; 305: 1395-1399.

41. Von Mutius E, Martinez FD, Fritzsch C, Nicolai T, Roell G, Thiemann H-H. Prevalence of asthma and atopy in two areas of West and East Germany. Am J Respir Crit Care Med 1994; 149: 358-364.

42. Nowak D, Heinrich J, Beck E, et al. Differences in respiratory symptoms between two cities in Western and Eastern Germany: the first report in adults (Abstract). Am Rev Respir Dis 1993; 147: A378.

43. Klein K, Dathe R, Gollnitz S, Jager L. Allergies: a comparison between two vocational schools in East and West Germany. Allergy 1992; 47 (Suppl. 12): 259.

44. Winkler G, Holtz H, Doring A. Comparison of food intakes of selected populations in former East and West Germany: results from the MONICA projects, Erfurt and Augsburg. Ann Nutr Metab 1992; 36: 219-234.

45. Akerblom HK, Viikari J, Uhari M, et al. Atherosclerosis precursors in Finnish children. I. General description of the cross-sectional study of 1980, and an account of the children's and families' state of health. Acta Paediatr Scand 1985; (Suppl. 318): 49-63.

46. Poysa L, Korppi M, Pietikainen M, Remes K, JuntunenBackman K. Asthma, allergic rhinitis and atopic eczema in Finnish children. Allergy 1991; 46: 161-165.

47. Moilanen T, Nikkari T, Viikari J, et al. Atherosclerosis precursors in Finnish children and adolescents. V. Fatty acid composition of serum cholesteryl esters: regional differences in Finland. Acta Paediatr Scand 1985; (Suppl. 318): 111-117.

48. Nakagomi T, Itaya H, Tominaga T, Yamaki M, Hisamatsu S, Nakagomi O. Is atopy increasing? Lancet 1994; 343: 121-122.

49. Okita M, Yoshida S, Yamamoto J, et al. N-3 and n-6 fatty acid intake and serum phospholipid fatty acid composition in middle-aged women living in rural and urban areas in Okayama Prefecture. J Nutr Sci Vitaminol 1995; 41: 313-323.

50. Marmot MG, Adelstein AM, Robinson N, Rose GA. Changing social class distribution of heart disease. $\mathrm{Br}$ Med J 1978; 2: 1109-1112.

51. Peckham C, Butler N. A national study of asthma in childhood. J Epidemiol Commun Health 1978; 32: 79-85.

52. Hamman RF, Halil T, Holland WW. Asthma in schoolchildren: demographic associations and peak expiratory flow rates compared with children with bronchitis. Br J Prev Soc Med 1975; 29: 228-238.

53. Martinez FD, Wright AL, Taussig LM, Holberg CJ, Halonen M, Morgan WJ. Asthma and wheezing in the first 6 years of life. N Engl J Med 1995; 332: 133-138. 
54. Britton J, Pavord I, Richards K, et al. Socioeconomic status and allergen sensitivity in a random adult population sample. Am J Respir Crit Care Med 1995; 151: A31.

55. Gergen PJ, Turkeltraub PC, Kovar MG. The prevalence of allergic skin test reactivity to eight common aeroallergens in the US population: results from the second National Health and Nutrition Examination Survey. $J$ Allergy Clin Immunol 1987; 80: 669-679.

56. Williams HC, Strachan DP, Hay RJ. Childhood eczema: disease of the advantaged? BMJ 1994; 305: 1132-1135.

57. Van Horn LV, Ballew C, Liu K, et al. Diet, body size, and plasma lipids/lipoproteins in young adults: differences by race and sex. Am J Epidemiol 1991; 133: 9-23.

58. Fulton M, Thomson M, Elton RA, Brown S, Wood DA, Oliver MF. Cigarette smoking, social class and nutrient intake: relevance to coronary heart disease. Eur $J$ Clin Nutr 1988; 42: 797-803.

59. Bolton-Smith C, Smith WCS, Woodward M, TunstallPedoe H. Nutrient intakes of different social class groups: results from the Scottish Heart Health Study (SHHS). Br J Nutr 1991; 65: 321-335.

60. Miedema I, Feskens EJM, Heederik D, Kromhout D. Dietary determinants of long-term incidence of chronic nonspecific lung diseases: the Zutphen Study. Am J Epidemiol 1993; 138: 37-45.

61. Troisi RJ, Willett WC, Weiss ST, Trichopoulos D, Rosner B, Speizer FE. A prospective study of diet and adultonset asthma. Am J Respir Crit Care Med 1995; 151: 1401-1408.

62. Mosmann TR, Coffman RL. Th1 and Th2 cells: different patterns of lymphokine secretion lead to different functional properties. Annu Rev Immunol 1989; 7: 145-173.

63. Wierenga EA, Snoek M, de Groot C, et al. Evidence for the compartmentalization of functional subsets of CD4+ T-lymphocytes in atopic patients. J Immunol 1990; 144: 4651-4656.

64. LeGros GS, Ben-Sasson Z, Seder R, Finkelman FD, Paul WE. Generation of interleukin-4 producing cells in vivo and in vitro: IL-2 and IL-4 are required for in vitro generation of IL-4 producing cells. J Exp Med 1990; 172: 921-929.

65. Gajewski TF, Joyce J, Fitch FW. Antiproliferative effect of IFN- $\gamma$ in immune regulation. III. Differential selection of Th1 and Th2 murine helper T-lymphocyte clones using recombinant IL-2 and recombinant IFN- $\gamma$. $J$ Immunol 1989; 143: 15-22.

66. Snijdewint FGM, Kalinski P, Wieringa EA, Bos JD, Kapsenberg ML. Prostaglandin $\mathrm{E}_{2}$ differentially modulates cytokine secretion profiles of human T-helper lymphocytes. J Immunol 1993; 150: 5321-5329.

67. Gold KN, Weyand CM, Goronzy JJ. Modulation of helper T-cell function by prostaglandins. Arthritis Rheum 1994; 37: 925-933.

68. Roper RL, Phipps RP. Prostaglandin $\mathrm{E}_{2}$ and cAMP inhibit B-lymphocyte activation and simultaneously promote $\mathrm{IgE}$ and $\mathrm{IgG}_{1}$ synthesis. J Immunol 1992; 149: 2984-2991.

69. Roper RL, Brown DM, Phipps RP. Prostaglandin $\mathrm{E}_{2}$ promotes B-lymphocyte Ig isotype switching to IgE. $J$ Immunol 1995; 154: 162-170.

70. Hwang D. Essential fatty acids and immune response. FASEB J 1989; 3: 2052-2061.

71. Knapp HR, Fitzgerald GA. The antihypertensive effects of fish oil. N Engl J Med 1989; 320: 1037-1043.

72. Blair IA, Prakash MA, Dougherty RM, Iacono JM. Dietary modification of $\omega-6$ fatty acid intake and its effect on urinary eicosanoid excretion. Am J Clin Nutr 1993; 57: 154-160. 